\title{
USING BIOTIC AS ALTERNATIVES TO CONTROL POWDERY MILDEW IN IRRADIATED CUCUMBER SEEDS
}

\author{
Ahmed S. M. Faris ${ }^{* 1}$, B.M. Ahmed ${ }^{2}$, M.Y.H. Abdalla ${ }^{1}$, A.A. Abdalla and G.R. Hassan ${ }^{3}$ \\ 1. Egypt. Authority Atomic Energ., Cent. Nuclear Res., Egypt \\ 2. Dept. Plant Prod., Fac. Environ. Agric. Sci., Arish Univ., Egypt \\ 3. Fac. Sci., Zagazig Univ., Egypt
}

\section{ABSTRACT}

Inducing resistance against powdery mildew caused by Sphaerotheca fuliginea in cucumber (cv. Beta Alfa) was investigated under filed conditions as fungicides alternatives. Biotic inducers (Bacillus subtilis) were sprayed onto the upper two true cucumber leaves. And water was used as negative control. Further, specific activities of defense-related enzymes (peroxidase, polyphenol-oxidase,catalses) and total phenols were spectrophotometrically measured in cucumber leaves and after inoculation with fungal spores. Results showed that, biotic tested inducers reduced the disease severity on the treated leaves, increased (plant length, root length, and plant dry weight) and increased the activities of defense-related enzymes, low doses of gamma radiation increased the vegetative growth specially doses at 15 and 20 Gray (Gy).

Key words:Cucumber, powdery mildew, Sphaerotheca fuliginea, Bacillus subtilis, gamma radiation, peroxidase activity, poly phenol oxidase, catalse activity, total phenols.

\section{INTRODUCTION}

Cucumber (Cucumis sativus L.) is one of the most important economic vegetable crops of those belong to family Cucurbitaceae. The economic importance of this crop appears in both local consumption and exportation purposes. Cucumber is grown either in the open field or under protected houses (Hanam et al., 1978).

Egypt is among top ten cucumber producing countries FAO STAT data (2012). Powdery mildew is a common disease of both domesticated and wild species of cucurbits; it is one of the most destructive leaf diseases, affecting mainly cucumber (Cucumis sativus L.) among the several cucurbits (Zatarin et al., 2005). Biological control of disease using biological agent such as Tirchoderma. spp and Bacillus subtilis for controlling foliar pathogenic fungi has been recorded by many researchers (Elad, 2000; Abd ElMoneim, 2004; Mahdy et al, 2006).

In Egypt, Ahmed (1995) mentioned that powdery mildew disease on cucumber was caused by Sphaerotheca fuliginea not $E$. cichoracearum. Mosa (1997) indicated that Powdery mildew of cucumber is one of the most important foliar diseases attacking cucumber plant in Egypt and other countries. Abd-El-Sayed (2000) reported that the casual agent of powdery mildew on cucumber in Egypt was Sphaerotheca fuliginea, not E. cichoracearum. Meliki and Marouani (2010) concluded that irradiated and not irradiated wheat seed showed no significant differences at low dose.

Borzouei et al. (2010) results showed that a radiation dose of 15 Gy caused

\footnotetext{
* Corresponding author: Tel.: +201129221381

E-mail address: asaladin50@gmail.com
} 
improvements in chickpea dry weight in contrast to 0 Gy doses of gamma rays. This study aimed to use biotic as alternative safe methods to control cucumber powdery mildew.

\section{MATERIALS AND METHODS}

Two filed experiments were carried out during growing seasons 2013-2014 and 2014-2015 at experimental farm, Department of Plant Research, Nuclear Research Center (NRC), Atomic Energy Authority, Inshas, Egypt.

\section{Plant Materials}

Cucumber seeds (Cucumis sativus L.) cv. (Beita Alpha F.1), obtained from Agriculture Research Center, Giza, Egypt, were sown on August and September of 2013 and 2014, growing seasons respectively.

\section{Irradiation of Gamma Rays}

Dry seeds of cucumber were kept in small plastic trays (100 g. each) and exposed to Gamma rays $\left(\mathrm{Co}^{60}\right)$ at 5 -doses, $0,10,15,20$, and 25 Gray (Gy). irradiation took place at Nuclear Research Center, Inshas, Egypt.

\section{Source of Microorganisms}

\section{Source of Sphaerotheca fuliginea conidia}

Conidia were harvested, according to Nair et al. (1962), from young cucumber leaves which showed extensive powdery mildew symptoms.

Old conidia were omitted and the newly ones were used in the laboratory trials.

\section{Source of Bacillus subtills}

Bacillus subtills bacteria were obtained from (Mersin center) Ain Shams University, Egypt. Concentrations used $10 \times 10^{10}$ and $10 \times 10^{12} \mathrm{Cfu} / \mathrm{ml}$.

\section{Disease assessment}

Disease assessment was conducted at 12 days after inoculation (field conditions).
Inoculated plants were carefully examined to estimate the severity of infection by powdery mildew disease as affected by the different tested treatments was depending on the devised scale (0-4) by (Reuveni et al., 2000) using the following formula:

Disease severity $(\%)=(\Sigma(\mathrm{n} \times \mathrm{v}) / 5 \mathrm{~N} \times 100$.

Where $\mathrm{n}=$ number of infected leaves in each category; $\mathrm{v}=$ numerical values of each category; $\mathrm{N}=$ total number of the infected leaves.

\section{Inoculation}

Cucumber leaves were carried out from Ain Sahms University, Faculty of Agriculture, Egypt and kept in paper pages. The cucumber host was grown in field (field conditions followed), and at first two true leaves expansion, the infected leaves were allowed to remain on the plants by leaf contact and indirect transfer was made. Then the heavy infected were collected and the spore suspension was poured into a volumetric flask. The flask was shaken for a few minutes before counting the spores by haemocytometre. The spore suspension was adjusted to a concentration of $10.32 \times 10$ spores per $\mathrm{ml}$.

\section{Enzymes assay}

Peroxidase activity was measured by a modified method with guaiacol (Angelini $\boldsymbol{e t}$ al. 1990). The activity of Poly phenol oxidase was determined according to the method of (Esterbauer et al., 1977). Catalase activity was determined with spectrophotometric method at $240 \mathrm{~nm}$ according to (Tkhemaladze and Kvesitadze, 1975). Total Phenols were determined by using Folin- Ciocalteu method with catechol according to (Singleton and Rossi, 1965).

\section{Statistic analysis}

The Data for both seasons were statistically analyzed using split plot design analysis according to (Snedecor and Cochran, 1982) multiple range test at 0.05 levels. 


\section{RESULTS AND DISCUSION}

\section{Effect of Certain Doses of Gamma Irradiation on Plant Morphological Characteristics}

\section{First season trial (2013)}

Data in Table 1 showed that the tested gamma doses except the dose at 25 Gray had significant impact on the morphological characters (plant length, root length, leaf length, and leaf width and plant dry weight) of treated cucumber plants infected with powdery mildew as compared with untreated (0 Gy) after 40days of planting. The highest plant length, root length, leaf length, leaf width and plant dry weight $(34 \mathrm{~cm}, 6.5 \mathrm{~cm}$, $6.3 \mathrm{~cm}, 6.7 \mathrm{~cm}$ and $3.7 \mathrm{~g}$ ) detected with 20 Gy as compared with control treatment i.e., untreated (0Gy) $(28.3 \mathrm{~cm}, 4.2 \mathrm{~cm}, 5 \mathrm{~cm}, 4.5$ $\mathrm{cm}$ and $2.7 \mathrm{~g}$ ), the highest tested gamma irradiation dose (25 Gy) had detrimental effect on plant growth $(29.7 \mathrm{~cm}, 4.7 \mathrm{~cm}, 5.5$ $\mathrm{cm}, 4.7 \mathrm{~cm}$ and $2.8 \mathrm{~g}$ ).

\section{Second season trial (2014)}

In the second season trial (2014), the obtained results showed the same trend. All teased gamma doses significantly increase (plant length, root length, leaf length, leaf width, plant dry weight) as compared with control treatment un irradiated or (0Gy) except dose at $25 \mathrm{~Gy}$.

The highest plant length, root length, leaf length, leaf width and plant dry weight $(37.7 \mathrm{~cm}, 7 \mathrm{~cm}, 6.7 \mathrm{~cm}, 6.8 \mathrm{~cm}$ and $3.7 \mathrm{~g})$ were detected with 20Gy as compared with control treatment (untreated or without radiation $0 \mathrm{~Gy})(30.3 \mathrm{~cm}, 5.2 \mathrm{~cm}, 5.2 \mathrm{~cm}, 2.5 \mathrm{~cm}$ and $2.9 \mathrm{~g}$ ). While the highest tested gamma radiation dose $(25 \mathrm{~Gy})$ also had detrimental effect of the tested plant characteristics $(30.3 \mathrm{~cm}, 5 \mathrm{~cm}, 5.7 \mathrm{~cm}, 5 \mathrm{~cm}$ and $3.1 \mathrm{~g})$

Statistically there were significant differences in the morphological characteristic among tested gamma doses and control treatment (0Gy) expect dose at $25 \mathrm{~Gy}$.
In general, all growth parameters were increased gradually with increasing doses of gamma rays up to 15 and 20 Gy irradiated seeds with 15 and 20 Gy seems to be the best doses for increasing all vegetative growth parameters these results are in harmony with those of (Veeresh et al., 1995) studied on dry seeds of been, exposed to different gamma ray doses to study their effect on various plant characters like germination, shoot length, root length, fresh and dry weight of plants. The results showed that there was more reduction at higher doses compared to lower doses for all the characters.

Muhkin et al. (1979) stated that the greatest stimulation effect during presuming gamma irradiations are established when cabbage seeds treated with doses vary from 3 to $8 \mathrm{~Gy}$ on the other hand, the results of vegetative growth seemed to decrease with increasing of radiation doses.

Kim et al. (2001) investigated that the effect of low doses of gamma radiation on the field growth parameters 45 days after planting of mustered seeds noticeably at the entire low dose irradiation group.

\section{Effect of Bacillus subtilis and Certain Doses of Gamma Irradiation on Disease Severity}

Garg et al. (1972) found that Irradiated barley seeds with 15 and $20 \mathrm{~Gy}$, seems to be the best doses for increasing all vegetative growth parameters such increments in vegetative growth could be referred to the irradiation improved plant growth, maintained an active metabolism in plants, cytological and physiological changes at cellular level inducted by gamma radiation.

In the first season trial (2013), the highest plant length was observed with B.subtilis $10 \times 10^{10}$ and $10 \times 10^{12}$ (30.3 and $31.7 \mathrm{~cm}$ ) as compared with control untreated $(28.3 \mathrm{~cm})$, for root length 5.3 and $6 \mathrm{~cm}$ as compared with control i.e. untreated $5 \mathrm{~cm}$, for plant dry weight $3.5 \mathrm{~g}$ and $3.6 \mathrm{~g}$ as compared with control untreated $2.7 \mathrm{~g}$. 
Table (1): Effect of certain doses of gamma irradiation on plant morphological characteristics in cucumber plant.

\begin{tabular}{ccccccc}
\hline \multicolumn{7}{c}{ Plant morphological characters } \\
\hline \multirow{2}{*}{ Radiation (Gy) } & \multicolumn{1}{c}{ Plant length (cm) } & \multicolumn{2}{c}{ Root length (cm) } & \multicolumn{2}{c}{ Plant dry weight (g) } \\
\cline { 2 - 7 } & Seas.1 & Seas.2 & Seas.1 & Seas.2 & Seas.1 & Seas.2 \\
\hline 0 & $28.3 \mathrm{~h}$ & $30.3 \mathrm{j}$ & $4.2 \mathrm{~g}$ & $5.2 \mathrm{f}$ & $2.7 \mathrm{k}$ & $2.9 \mathrm{i}$ \\
10 & $30.7 \mathrm{ef}$ & $33 \mathrm{gh}$ & $5.2 \mathrm{e}$ & $5.8 \mathrm{e}$ & $3 \mathrm{i}$ & $3.3 \mathrm{~g}$ \\
15 & $32.7 \mathrm{de}$ & $35.7 \mathrm{e}$ & $6.2 \mathrm{bc}$ & $6.3 \mathrm{de}$ & $3.2 \mathrm{~h}$ & $3.5 \mathrm{f}$ \\
20 & $34 \mathrm{c}$ & $37.7 \mathrm{c}$ & $6.5 \mathrm{~b}$ & $7 \mathrm{bc}$ & $3.7 \mathrm{~g}$ & $3.7 \mathrm{e}$ \\
25 & $29.7 \mathrm{~g}$ & $30.3 \mathrm{j}$ & $4.7 \mathrm{f}$ & $5 \mathrm{f}$ & $2.8 \mathrm{k}$ & $3.1 \mathrm{~h}$ \\
\hline
\end{tabular}

Means in the same column followed by different letters indicate significant difference (LSD, $\mathrm{P}>0.05$ )

Table (2-a): Effect of Bacillus subtilis and certain doses of gamma radiation on disease severity during second season of 2013.

\begin{tabular}{cccc}
\hline \multicolumn{4}{c}{ Diseases severity (\%) season (2013) } \\
\hline \multirow{2}{*}{ Gamma radiation (Gy) } & Control & \multicolumn{1}{c}{ Bacillus subtilis (cfu/ml) } \\
\cline { 3 - 4 } & & $\mathbf{1 0 x 1 0}^{\mathbf{1 0}}$ & $\mathbf{1 0 x 1 0}^{\mathbf{1 2}}$ \\
\hline 0 & $38.80 \mathrm{a}$ & $18.60 \mathrm{~b}$ & $19.30 \mathrm{~b}$ \\
10 & $38.40 \mathrm{a}$ & $18.40 \mathrm{~cd}$ & $18.33 \mathrm{de}$ \\
15 & $38.60 \mathrm{a}$ & $18.20 \mathrm{c}$ & $18.50 \mathrm{~d}$ \\
20 & $38.60 \mathrm{a}$ & $18.60 \mathrm{~b}$ & $18.60 \mathrm{~cd}$ \\
25 & $38.60 \mathrm{a}$ & $18.60 \mathrm{~b}$ & $18.90 \mathrm{c}$ \\
\hline
\end{tabular}

Means in the same column followed by different letters indicate significant difference (LSD, $\mathrm{P}>0.05$ ).

Table (2-b): Effect of Bacillus subtilis and certain doses of gamma radiation on disease severity during second season of 2014.

\begin{tabular}{cccc}
\hline \multicolumn{4}{c}{ Diseases severity (\%) season (2014) } \\
\hline \multirow{2}{*}{ Gamma radiation (Gy) } & Control & \multicolumn{1}{c}{ Bacillus subtilis $(\mathbf{c f u} / \mathbf{m l})$} \\
\cline { 3 - 4 } & & $\mathbf{1 0 \times 1 0} \mathbf{1 0}^{\mathbf{1 0}}$ & $\mathbf{1 0 x 1 0}$ \\
\hline 0 & $37.60 \mathrm{a}$ & $19.13 \mathrm{~b}$ & $19.30 \mathrm{~b}$ \\
10 & $37.33 \mathrm{a}$ & $18.73 \mathrm{c}$ & $18.80 \mathrm{c}$ \\
15 & $37.33 \mathrm{a}$ & $18.50 \mathrm{~cd}$ & $18.63 \mathrm{~cd}$ \\
20 & $37.33 \mathrm{a}$ & $18.30 \mathrm{~d}$ & $18.03 \mathrm{~d}$ \\
25 & $37.40 \mathrm{a}$ & $19.03 \mathrm{bc}$ & $19.20 \mathrm{bc}$ \\
\hline
\end{tabular}


In the second season the same trend was observed. All treatments significantly increased morphological characteristics the highest plant length was observed with $B$. subtilis $10 \times 10^{10}$ and $10 \times 10^{12}(31.3$ and $31.3 \mathrm{~cm}$ ) as compared with control untreated $30.3 \mathrm{~cm}$, for root length the value were 5.5 and $6.2 \mathrm{~cm}$ as compared with control i.e. untreated $5.2 \mathrm{~cm}$, for plant dry weight $3.6 \mathrm{~g}$ and $3.7 \mathrm{~g}$ as compared with control untreated $2.9 \mathrm{~g}$.

Statistically, there were significant differences in the morphological characters among tested treatments and control treatment (untreated) in first and second season trial.

These results are in agreement with Compants et al. (2005) who indicated that Bacillus subtilis not only antagonized several pathogenic fungi but also promoted the seedling growth and increased its stress tolerance. Regarding to interaction between Bacillus subtilis and doses of gamma irradiation, Bacillus subtilis $10 \times 10^{10}$ and $10 \times 10^{12}$ detected with dose at 15 and 20 Gy were the most effective.

\section{Effect of Bacillus subtilis and Certain Doses of Gamma Radiation on Peroxidase, Polyphenol Oxidase and \\ Catalase Activity}

As shown in Fig. 1 all treatments Bacillus subtilis $10 \times 10^{10}$ and $10 \times 10^{12} \mathrm{cfu} / \mathrm{ml}$ elevated peroxidase, catalase and polyphenol oxidase compared with control i.e., The highest Peroxidase activity were observed with B.subtilis $10 \times 10^{10}$ and $10 \times 10^{12} \mathrm{cfu} / \mathrm{ml}$ (38 and 37 Unit/g fresh weight $/ 5 \mathrm{~min}$ ) as compared with lowest enzyme activity in control treatment i.e., untreated (22Unit/g fresh weight $/ 5 \mathrm{~min}$ )

Pertaining to poly phenol oxidase, the highest polyphanol oxidase activity was observed B.subtilis $10 \times 10^{10}$ and $10 \times 10^{12}$ $\mathrm{cfu} / \mathrm{ml}$ (30 and $33 \mathrm{Unit} / \mathrm{g}$ fresh weight $/ 5 \mathrm{~min}$ ).

Pertaining to catalase activity, the highest catalase activity was observed B.subtilis $10 \times 10^{10}$ (4 Unit/g fresh weight $/ 3 \mathrm{~min}$ ) as compared with lowest enzyme activity in control treatment untreated (3Unit /g fresh weight/3 min). Generally Bacillus subtilis significantly increase antioxidant enzymes compared with control (untreated) are in agreement with Yang et al. (2009) who found that antioxidant enzymes catalase and peroxidase improved significantly $128 \%$ and $81.5 \%$ over control after inoculated eggplants with Bacillus subtilis.

Regarding to interaction between Bacillus subtilis and doses of gamma irradiation, Bacillus subtilis $10 \times 10^{10}$ and $10 \times 10^{12}$ detected with dose at 15 and 20 Gy were the most effective. Each figure represents the mean of three replicates.

\section{Effect of Bacillus subtilis and Certain Doses of Gamma Radiation on Total Phenols}

Data in Fig. 2 showed that all treatments Bacillus subtilis $10 \times 10^{10} \mathrm{cfu} / \mathrm{ml}$.

Each figure represents the mean of three replicates and $10 \times 10^{12} \mathrm{cfu} / \mathrm{ml}$ significantly elevated the total phenols 13 and $14 \mathrm{mg} / \mathrm{g}$ fresh weight as compared with control i.e., untreated $7 \mathrm{mg} / \mathrm{g}$ fresh weight. These results are in agreement with Mahdy et al. (2006) found that Bacillus filtrate increase total phenol $(48.71 \%$ over control) against cucumber powdery mildew.

Regarding to interaction between gamma irradiation and Bacillus subtilis, the highest total phenols induced by Bacillus subtilis $10 \times 10^{12}$ at $20 \mathrm{~Gy}$. 
Table (3-a): Effect of Bacillus subtilis and certain doses of gamma radiation on plant length (cm).

\begin{tabular}{ccccccc}
\hline \multicolumn{7}{c}{ Plant Length (cm) } \\
\hline Bacillus subtilis (cfu/ml) & \multicolumn{2}{c}{ 0 } & \multicolumn{1}{c}{$\mathbf{1 0 x 1 0}^{\mathbf{1 0}}$} & \multicolumn{2}{c}{$\mathbf{1 0 x 1 0}^{\mathbf{1 2}}$} \\
\hline Radiation (Gy) & Seas.1 & Seas.2 & Seas.1 & Seas.2 & Seas.1 & Seas.2 \\
\hline $\mathbf{0}$ & $28.3 \mathrm{~h}$ & $30.3 \mathrm{j}$ & $30.3 \mathrm{~g}$ & $31.3 \mathrm{j}$ & $31.7 \mathrm{ef}$ & $32.3 \mathrm{k}$ \\
$\mathbf{1 0}$ & $30.7 \mathrm{fg}$ & $33 \mathrm{gh}$ & $32.3 \mathrm{de}$ & $33.3 \mathrm{fgh}$ & $33.3 \mathrm{~cd}$ & $34 \mathrm{fg}$ \\
$\mathbf{1 5}$ & $32.7 \mathrm{de}$ & $35.7 \mathrm{e}$ & $37 \mathrm{~b}$ & $40 \mathrm{c}$ & $37.7 \mathrm{ab}$ & $41.7 \mathrm{~b}$ \\
$\mathbf{2 0}$ & $34 \mathrm{c}$ & $37.7 \mathrm{~d}$ & $38.3 \mathrm{a}$ & $42.7 \mathrm{ab}$ & $38.7 \mathrm{a}$ & $43.3 \mathrm{a}$ \\
$\mathbf{2 5}$ & $29.7 \mathrm{~g}$ & $30.3 \mathrm{j}$ & $31.7 \mathrm{ef}$ & $33.3 \mathrm{fgh}$ & $33.3 \mathrm{~cd}$ & $34.3 \mathrm{f}$ \\
\hline
\end{tabular}

Means in the same column followed by different letters indicate significant difference (LSD, P $>0.05$ ).

Table (3-b): Effect of Bacillus subtilis and certain doses of gamma radiation on root length (cm).

\begin{tabular}{|c|c|c|c|c|c|c|}
\hline \multicolumn{7}{|c|}{ Root length (cm) } \\
\hline Bacillus subtilis (cfu/ml) & \multicolumn{2}{|c|}{$\mathbf{0}$} & \multicolumn{2}{|c|}{$10 \times 10^{10}$} & \multicolumn{2}{|c|}{$10 \times 10^{12}$} \\
\hline Radiation (Gy) & Seas.1 & Seas. 2 & Seas.1 & Seas. 2 & Seas.1 & Seas.2 \\
\hline $\mathbf{0}$ & $5 \mathrm{~g}$ & $5.2 \mathrm{~h}$ & $5.3 \mathrm{fg}$ & $5.5 \mathrm{gh}$ & $6 \mathrm{cde}$ & $6.2 \mathrm{de}$ \\
\hline 10 & $5.5 \mathrm{efg}$ & $5.7 \mathrm{fg}$ & 6 cde & $6.3 \mathrm{cde}$ & $6.5 \mathrm{~cd}$ & $6.5 \mathrm{~cd}$ \\
\hline 15 & $6 \mathrm{cde}$ & $6.3 \mathrm{cde}$ & $7.2 b$ & $7.2 b$ & $7.7 \mathrm{ab}$ & $8.2 \mathrm{a}$ \\
\hline 20 & $6.3 \mathrm{~cd}$ & $6.7 \mathrm{c}$ & $7.5 \mathrm{ab}$ & $7.3 b$ & $7.8 \mathrm{a}$ & $8 \mathrm{a}$ \\
\hline 25 & $5.5 \mathrm{efg}$ & $5.7 \mathrm{fg}$ & $6 \mathrm{cde}$ & $6.2 \mathrm{de}$ & $5.8 \mathrm{def}$ & $6 \mathrm{ef}$ \\
\hline
\end{tabular}

Means in the same column followed by different letters indicate significant difference (LSD, $\mathrm{P}>0.05)$.

Table (3-c): Effect of Bacillus subtilis and certain doses of gamma radiation on plant dray weight (g).

\begin{tabular}{|c|c|c|c|c|c|c|}
\hline \multicolumn{7}{|c|}{ Plant dry weight (g) } \\
\hline Bacillus subtilis (cfu/ml) & & & & & & $10^{12}$ \\
\hline Radiation (Gy) & Seas.1 & Seas.2 & Seas.1 & Seas.2 & Seas.1 & Seas.2 \\
\hline $\mathbf{0}$ & $2.7 \mathrm{k}$ & $2.9 \mathrm{i}$ & $3.5 \mathrm{fg}$ & $3.6 \mathrm{ef}$ & $3.6 \mathrm{f}$ & $3.7 \mathrm{e}$ \\
\hline 10 & $3 \mathrm{i}$ & $3.3 \mathrm{~g}$ & $4 \mathrm{e}$ & $4.1 d$ & $4.2 \mathrm{~d}$ & $4.2 \mathrm{~d}$ \\
\hline 15 & $3 . \mathrm{h} 2$ & $3.5 f$ & $4.5 b$ & $4.7 b$ & $4.6 \mathrm{a}$ & $4.8 \mathrm{ab}$ \\
\hline 20 & $3.5 \mathrm{~g}$ & $3.7 \mathrm{e}$ & $4.7 \mathrm{a}$ & $4.8 \mathrm{a}$ & $4.7 \mathrm{a}$ & $4.9 \mathrm{a}$ \\
\hline 25 & $2.8 \mathrm{j}$ & $3.1 \mathrm{~h}$ & 4.1de & $4.2 \mathrm{~d}$ & $4.3 \mathrm{c}$ & $4.4 \mathrm{c}$ \\
\hline
\end{tabular}

Means in the same column followed by different letters indicate significant difference (LSD, P $>0.05)$. 

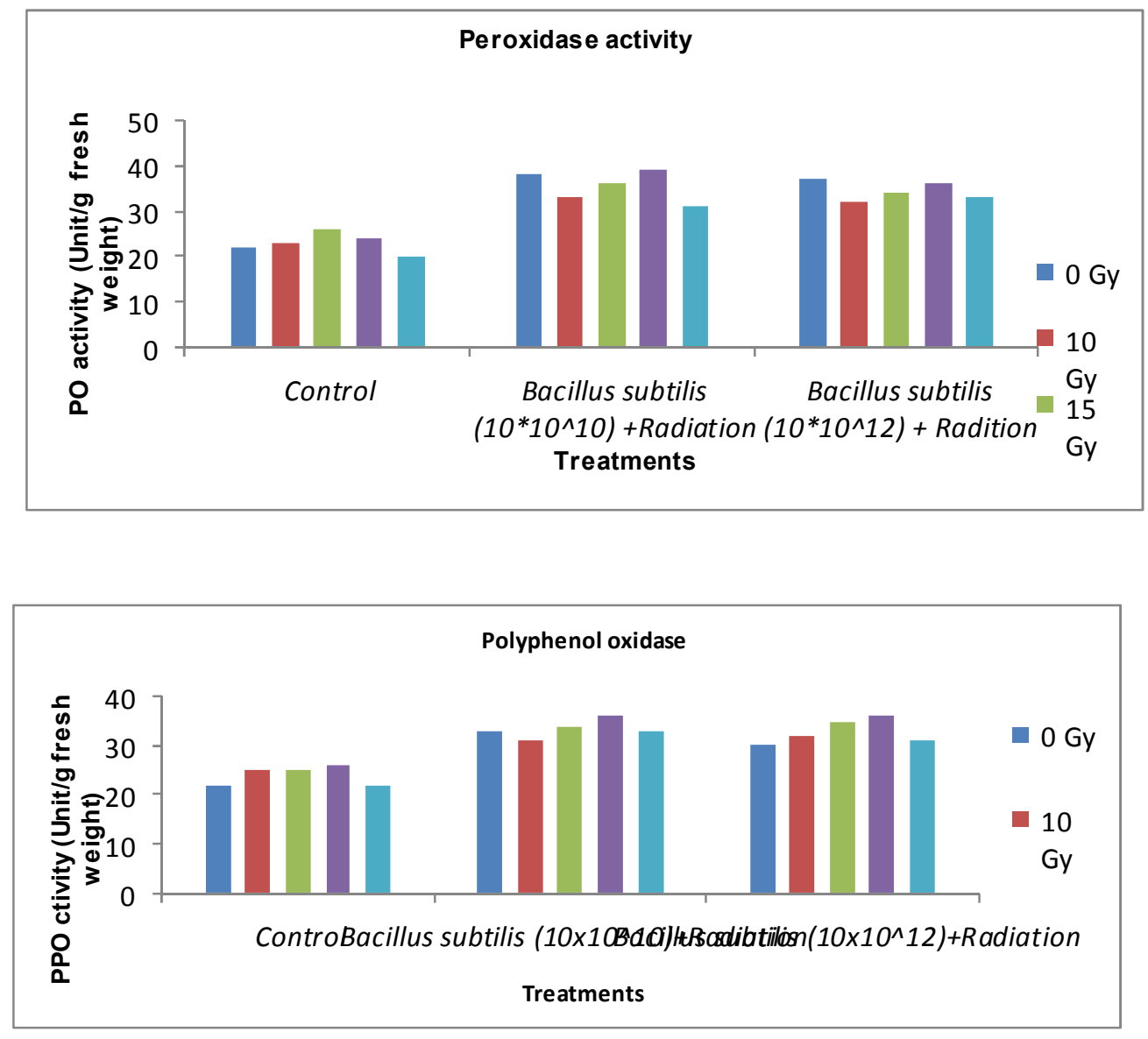

(B)

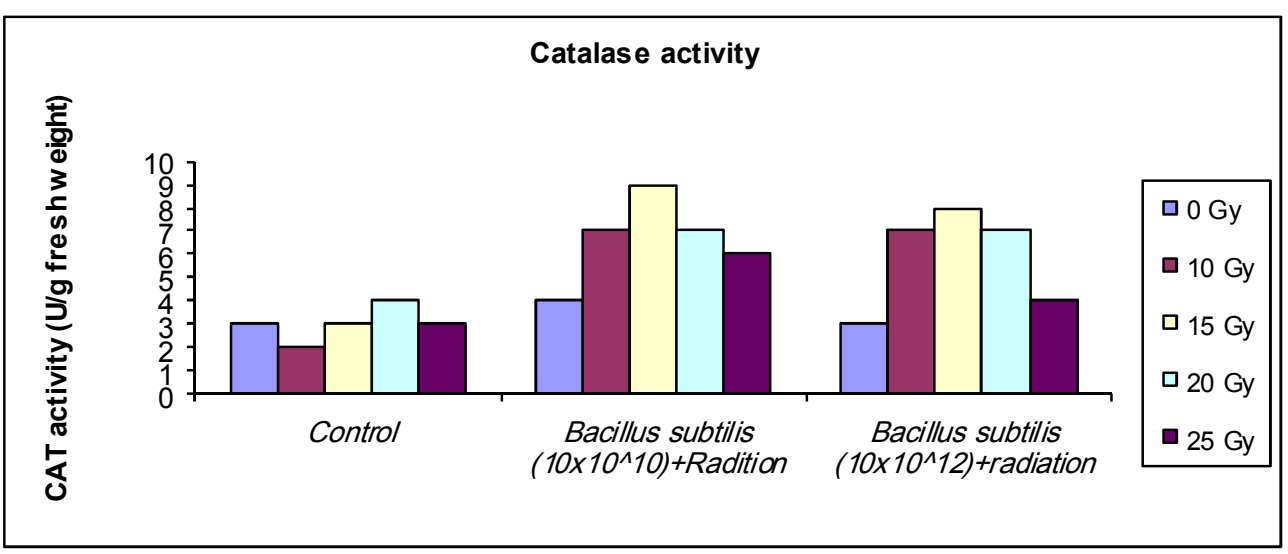

(C)

Fig. (1): Effect of Bacillus subtilis and certain doses of gamma irradiation on peroxidase activity (A), Polyphenol oxidase (B) and catalase activity (c). 


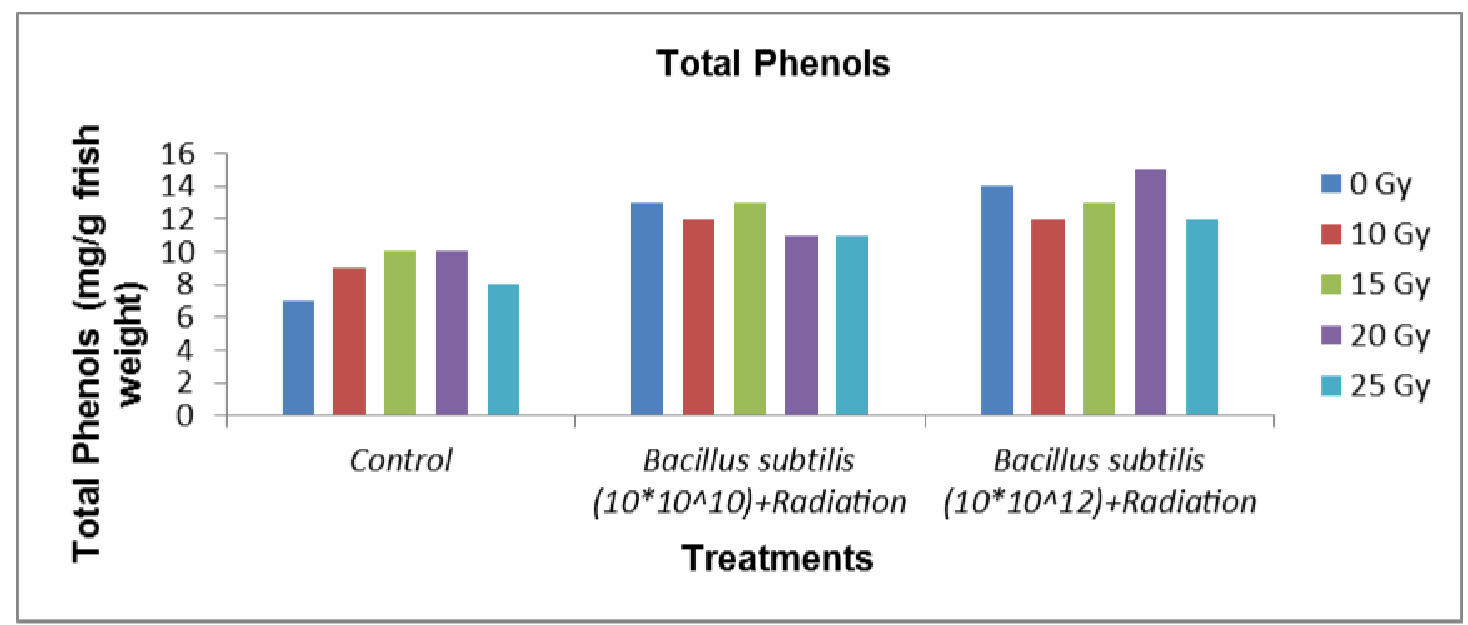

Fig. (2): Effect of Bacillus subtilis and certain doses of gamma radiation on total phenols

\section{REFERENCES}

Abd El-Moneim, M.L. (2004). Integrated system to protect cucumber plants in greenhouses against diseases and pests underorganic farming conditions. Egypt. J. Agric. Res., 82 (2): 1-9.

Abdel-Sayed, M.H.F. (2000). Studies on powdery mildew disease of cucurbits under protected cultivation. M.Sc. Thesis, Dept. Plant Path., Fac. Agric., Cairo Univ., Egypt.

Ahmed, A.S.Y. (1995). Studies on the powdery mildew disease of cucurbits. M.Sc Thesis, Fac. of Agric., Al-Azhar Univ. and plant extracts. J. Agric. Sci., 2: 220-230.

Angelini, R.; Manes, F. and Federico, R. (1990). Spatial and functional correlation between iamine-oxidase and peroxidase activities and their dependence upon deetiolation and wounding in chick-pea stems. Planta., 182: 89- 96.

Borzouei, A.; Kafi, M.; Khazaei, H.; Naseriyam, B. and Majedabadi, A. (2010). Effect of Gamma radiation on germination and physiological wheet (Triticum aestivum L.) seedling, Pak. J. Bot., 42(4): 2281- 2290.
Compants, S.; Duffy, B.; Nowak, J.; Clement, C. and Barka, E.A. (2005). diseases: Principles, mechanisms of action, and future prospects, Appl. and Environ. Microbiol., 71: 4951-4959.

Elad, Y. (2000). Biological control of foliar pathogens by means of Trichoderma harzianum and potential modes of action. Crop Prot., 19:709-714.

Esterbauer, H.; Schwarzl, E. and Hayn, M. (1977). A rapid assay for Factors affecting acquired resistance in Erysiphe cichoracearum the causal organism of cucumber powdery mildew. Agric. Res. Rev., 68 (3): 521-528.

Garg, O.K.; Misra, B.C. and Singh, B.P. (1972). Effect of pre- sowing exposure of seeds to Gamma radiation on the drought resistance behavior of barley plants. Plant and Soil, 36: 39-45.

Hanam, J.J., Holley, W.D. and Goldsberry, K.L. (1978). Greenhouse management, Springer-Verlag, Berlin. Heidelberg and New York, 530.

Kim, J.; Beak, M and Lee, Y. (2001). Effects of low dose gamma radiation on the dormancy, breaking and physiological activity of (Dejima) seed potato. Chungnam National Univ., Taejon (Republic of Koria) 24-25 May, 8 ref. 4 
figs, 1 tab. Avaialble from kns, Taejon (Koria).

Mahdy, A.; Abd El-Mageed, M.; Hafez, M. and Ahmed, G. (2006). Using alternatives to control cucumber powdery mildew under green- and commercial protected-house conditions. Fayoum J. Agric. Res. and Dev., 20 (2): 121-138

Meliki, M. and Marouani, A. (2010). Effect of Gamma rays irradiation on seed germination and growth of hard wheat. Environ. Chem. Lett., 8 (4): 307-310.

Mosa, A.A. (1997). Effect of foliar application of phosphate on cucumber powdery mildew. Annals. Agric. Sci. Ain Shams Univ. Cairo, 42:241-255.

Mukhin, V.; Gerpuski, D. and Selman, V. (1979). Effect of radiation main spear fresh and dry weight of broccoli and invrease of productivity of vegetables grown in either type. Rusting $\mathrm{J}$. Pochvoret, 25: (3) 44- 47.

Nair, K.R.; Sivan, S. and Ellingboe, A.H. (1962). A method of controlled inoculations with conidiospores of Erysiphe graminis var. tritici. Phytopathol., $52: 714$

Reuveni, R.; Dor, G.; Raviv, M.; Reuveni, M. and Tuzun, S. (2000).
Systemic resistance against Sphaerotheca fuliginea in cucumber plants exposed to phosphate in hydroponics system and its control by foliar spray of mono-potassium phosphate. Crop Prot., 19: 355-361

Singleton, V.L. and Rossi, J.A. (1965). Colorimetry of total phenolics with phosphomolybdic-phosphotungstic acid reagents. Ame. J. Enol. Vitic., 16 (3): 144-158.

Snedecor, G.W. and Cochran, W. (1982). Statistical Methods $7^{\text {th }}$ Ed. Aiwa State Univ. Press. Ame. Aiwa. USA.

Tkemaladaze, G. and Esitadeze, K.G. (1975). Enzymology Practical Tbilis in Georgian, 298.

Veeresh, L.; Shivashankar, H.; Shai, L. and Hittalmani, S. (1995). Effect of seed irradiation on some plant characteristics of winged bean. J. Agric. Sci., 29:1-4.

Yang, Z.; Liu, X.; Liu, Z.; Pang, J.; Qiu, J. and Yang, W. (2009). Effect of Bacillus Subtilis SY1 on antifungal activity and plant growth. Int. J. Agric. and Biol. Eng., 2 (4): 55-61.

Zatarin, M.; Cardoso, A. and FU, I. (2005). Horticultura Brasileira Rtado, E.L. Effitosde tipos de letie sorbe oidio en abobora plantadas no campo., 23 (2): 198-201. 
استخدام بدائل لمقاومة مرض البياض الاقيقى فى بذور الخيار المعاملة بالإشعاع

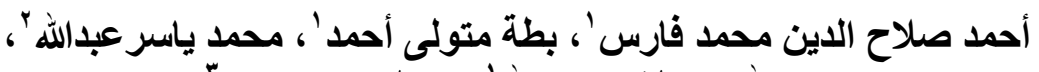

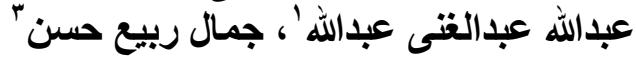

ا ـ الهيئة المصرية للطاقة الذرية، مركز البحوث الذرية، مصر.

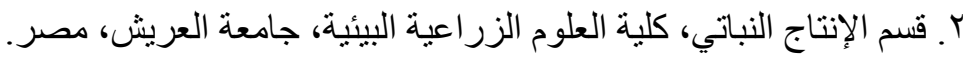

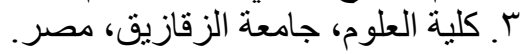

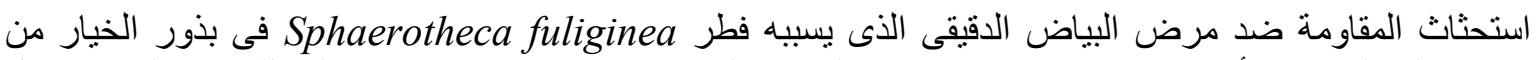

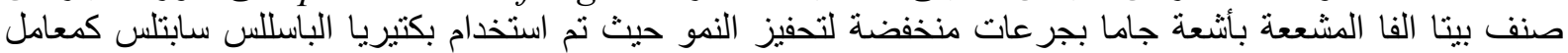

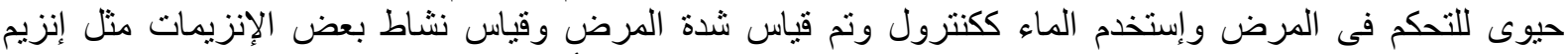

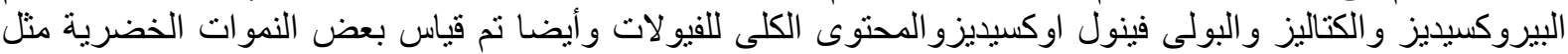

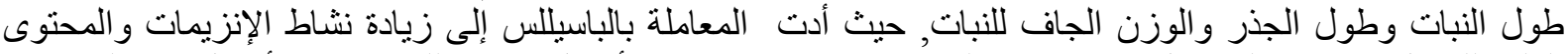

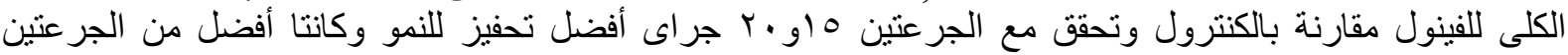

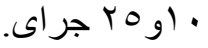
الكلمات الأسترشادية: البياض الدقيقى، بذور الخيار، المعاملة بالإشعاع. 